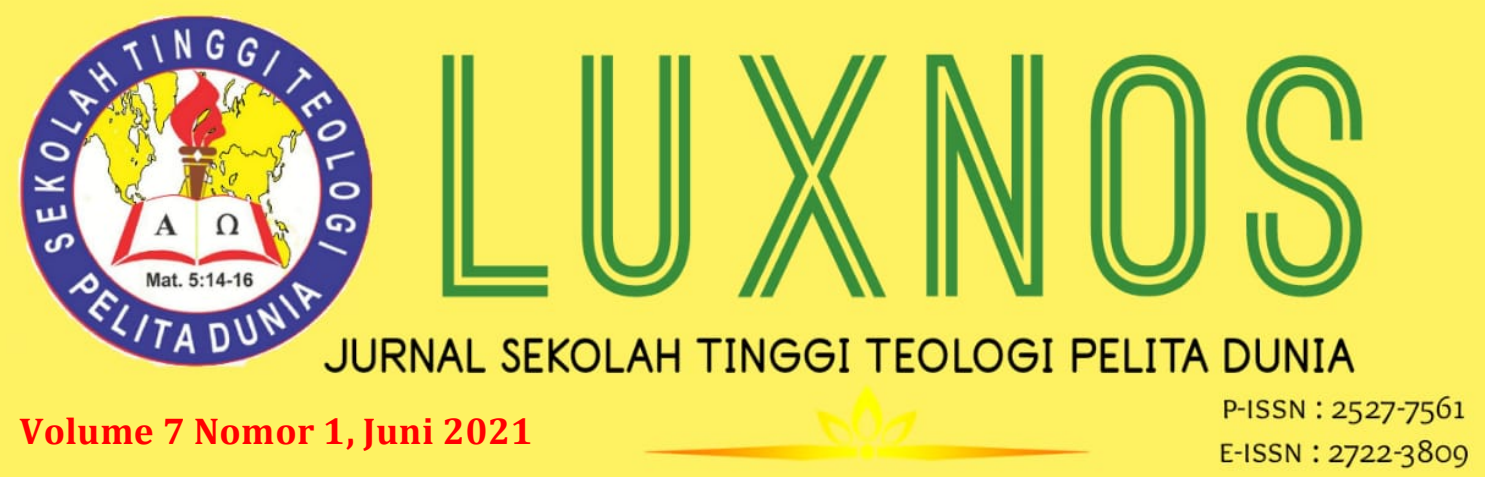

\title{
Pembelajaran PAK di Era Digital: Sikap Inklusivisme di Tengah Kemajemukan
}

\author{
Esti R. Boiliu \\ Universitas Kristen Indonesia \\ Program Studi Magister Pendidikan Agama Kristen \\ estireginaboiliu02@gmail.com
}

\begin{abstract}
This article contains a discussion of Christian Religius Education Learning in the Digital Age: Attitudes of Inclusivism in the midst of diversity. In the reality of people's lives, there are still many problems that arise with various conflicts that occur and are often linked to issues of ethnicity, race and religion in particular. There are also many attitudes that are exclusive or closed off and there is no desire to join other communities because they feel that their community is right. This is a fact that occurs in a pluralistic society. Therefore, Christian Religious Education in the digital age has a duty to teach inclusive attitudes amid diversity. The purpose of Christian Religious Education is to be able to realize the goals of national education through students and also to be present as a means of forming and unifying the nation in a pluralistic society of different religions, ethnicities, races, groups, and so on. What is done here is to live in tolerance, be aware of and follow the development of science and technology, be creative, innovative, and have high solidarity. The purpose of this research is to provide an understanding of how Christian Religious Education teaches an inclusive attitude amid diversity. The research method used in this article is literature study. The results of this article are compiled from various written sources that are not numbers, but from books, journals, the internet and other written media.
\end{abstract}

\section{Keywords: Christian Religious Education, Inclusivism, Plural Society}

\begin{abstract}
Abstrak: Artikel ini berisi pembahasan tentang Pembelajaran Pendidikan Agama Kristen pada Era Digital: Sikap Inklusivisme di tengah kemajemukan. Kenyataan yang terjadi dalam kehidupan masyarakat, muncul berbagai persoalan dan konflik yang sering dikaitkan dengan perbedaan suku, rasa, agama dan kebiasaan lainnya. Terdapat juga banyak sikap yang eksklusif atau tetutup dan tidak memiliki keinginan untuk bergabung dengan masyarakat lain karena merasa bahwa komunitasnya yang benar. Hal ini merupakan kenyataan yang terjadi dalam kehidupan masyarakat majemuk. Oleh kerena itu, Pendidikan Agama Kristen di Era digital memiliki tugas untuk mengajarkan sikap yang inklusif di tengah keberagaman. Pendidikan Agama Kristen bertujuan untuk membimbing serta
\end{abstract}


mengarahkan peserta didik menjadi pemersatu di tengah kemajemukan. Hal yang dilakukan di sini adalah hidup bertoleransi, sadar dan mengikuti perkembangan ilmu pengetahuan dan teknologi, kreatif, inovatif, serta memiliki solidaritas tinggi. Tujuan dari penelitian ini adalah untuk memberikan pemahaman tentang Pendidikan Agama Kristen dalam mengajarkan sikap inklusif di tengah kemajemukan. Penenelitian ini menggunakan metode studi pustaka yang mana hasil dari artikel ini dikumpulan dari berbagai sumber tertulis yang tidak berupa angka, melainkan dari buku-buku, jurnal, internet dan media tertulis lainnya.

Kata kunci: Pendidikan Agama Kristen, Inklusivisme, Masyarakat Majemuk

\section{Pendahuluan}

Perkembangan globalisasi terjadi sangat pesat dan cepat hingga mengakibatkan banyak perubahan pada segala bidang di seluruh aspek kehidupan manusia. Oleh karena itu, manusia dituntut untuk memiliki cara berpikir yang kreatif dalam menyikapi situasi ini.

Bangsa Indonesia merupakan bangsa majemuk yang terdiri dari berbagai pulau, suku, ras, tradisi, bahasa, agama dan latar belakang kehidupan sosial yang berbeda. Kehidupan keberagaman agama di tengah dunia ini mengakibatkan setiap orang memiliki persepsi tersendiri dalam menyatakan kebenaran agamanya. Oleh karena itu, kekristenan menganggap bahwa keberagaman budaya dan agama tentunya dapat memperlihatkan banyak aspek baik negatif maupun positif. Secara positif, kepercayaan pluralitas dapat menambah pemahaman Kristen secara realistis mengenai keberagaman sehingga pelayanan Kristen menjadi relevan dan lebih kontekstual dalam menjawab kebutuhan manusia. Secara negatif, kepercayaan dan pluralitas menyebabkan perbedaan pendapat yang menimbulkan konflik di antara keyakinan-keyakinan tersebut.

Bertambahnya kesadaran akan pluralitas agama, maka dapat menimbulkan tekanan yang lebih besar bagi iman Kristen dan relasinya dengan kepercayaan lain. Menjadi hal yang biasa apabila semua agama lahir dan hadir dengan kebenarannya masing-masing. Hal yang membedakan dalam melihat kebenaran tersebut terletak pada para penganutnya. Oleh sebab itu, lahirlah beberapa paham yang dapat dipakai sebagai pendekatan-pendekatan dalam memandang dan bersikap terhadap agama lain diantaranya paham eksklusivisme dan inklusivisme.

Eksklusivisme ialah cara pandang yang menganggap bahwa hanya agama atau kepercayaannya yang benar sedangkan inklusivisme ialah pandangan yang menerima bahwa agama lain juga mengandung kebenaran tapi keselamatan yang sesungguhnya hanya ada di dalam Yesus Kristus. Dalam Alkitab baik Perjanjian Lama maupun Perjanjian Baru, dapat ditemukan beberapa ayat yang menjelaskan tentang eksklusivisme dan inklusivisme. Meskipun demikian, bukan berarti paham eksklusivisme maupun inklusivisme dapat mengurangi konflik-konflik di antara para 
penganut agama-agama lain di luar Kekristenan. Oleh sebab itu, orang Kristen seharusnya berupaya untuk ikut serta dalam kegiatan agama yang lain supaya dapat memperkaya dan juga menyerap kebenaran yang mereka yakini.

\section{Metode Penelitian}

Penelitian ini menggunakan metode studi pustaka atau biasanya disebut metode kualitatif yang lebih berfokus pada hubungan-hubungan sosial di mana teori dikembangkan dari hasil penelitian yang tidak berupa angka. ${ }^{1}$ Dalam hal ini penulis melakukan penelitian terhadap beberapa sumber pustaka yang relevan untuk membahas topik tentang pembelajaran Pendidikan Agama Kristen di era digital yakni berperilaku inklusif di tengah kehidupan masyarakat majemuk. Dengan kata lain, penelitian ini menggunakan pendekatan tinjauan literatur ${ }^{2}$ atau sumber pustaka yang dianalisis kemudian diuraikan secara deskriptif tematis.

\section{Hasil dan Pembahasan}

Melihat kemajuan teknologi yang berkembang pesat dan mengikuti standar aturan yang berlaku secara nasional, Pendidikan agama Kristen tentu tidak bisa tinggal diam dan pasif. Pendidikan Agama Kristen baik dalam ranah akademik, yaitu dari sekolah dasar sampai Perguruan Tinggi Kristen dan juga dalam ranah gereja harus dapat menyesuaikan diri dengan kemajuan serta tuntutan yang ada. Pendidikan Agama Kristen menempati posisi yang penting untuk turut membawa nara didik agar mengikuti perkembangan informasi dan berbagai perangkat yang menyertainya. Hal ini bukan hanya supaya tidak dianggap ketinggalan zaman tetapi juga agar para akademisi Kristen secara menyeluruh dapat memberikan sumbangsih dan solusi bagi permasalahan masyarakat dalam berbagai hal.

Menurut Djoys Anneke Rantung, Pembelajaran Pendidikan Agama Kristen pada Era digital harus terus dikembangkan baik itu dalam hal paradigma, penggunaan metode dan kurikulum sehingga Pendidikan Agama Kristen tetap menginspirasi bahkan mendorong umat Kristiani untuk terlibat dalam upaya transformasi masyarakat. ${ }^{3}$ Djoys juga menjelaskan bahwa Indonesia pada umumnya memiliki masyarakat yang majemuk sehingga menimbulkan konflik yang bernuansa SARA. Melihat situasi ini, maka Pendidikan Agama Kristen berperan untuk menumbuhkembangkan keberagaman inklusif dan pluralis. Proses pembelajaran Pendidikan Agama Kristen diupayakan untuk meningkatkan kemampuan serta

\footnotetext{
1 Desi Sianipar, Peran Pendidikan Agama Kristen Di Gereja Dalam Meningkatkan Ketahanan Keluarga, Jurnal SHANNAN Volume 4 Nomor 1 (Maret, 2020): 73-92.

${ }^{2}$ Uwe Flick, An Introduction to Qualitative Research, (London: SAGE Publications, Ltd., 2014): 11-12, 66-70.

3 Djoys Anneke Rantung, Pendidikan Agama Kristen Dalam Kehidupan Masyarakat Majemuk, (Yogyakarta: Lintang Rasi Aksara, 2017), 101.
} 
merefleksikan realitas kemajemukan kepada peserta didik. Selain itu, Pendidikan Agama Kristen juga tentunya diharapkan untuk dapat mengatasi persoalan intoleransi dan fanatisme serta menjadi alternatif untuk upaya mengembangkan sikap toleransi di tengah kehidupan masyarakat mejemuk saat ini. Salah satu upaya Pendidikan Agama Kristen adalah menggunakan metode dialogi dan reflektif yaitu dapat mengajak nara didik untuk dapat merefleksikan kenyataan dari kemajemukan yang mana dapat juga mendalami nilai-nilai dari agama yang dianut kemudian mempraktekkan pengalaman tersebut. Upaya perkembangan Pendidikan Agama Kristen yang inklusif harusnya terus dilakukan supaya nara didik mengetahui serta menghargai perbedaan. Selain itu, nara didik diajar untuk memiliki kepekaan nilainilai kemanusiaan. ${ }^{4}$

\section{Pendidikan Agama Kristen}

Pendidikan Agama Kristen merupakan pendidikan yang bersumber dari Alkitab dan tujuannya adalah untuk mendewasakan para murid Kristus. ${ }^{5}$ Maksud dari pengertian ini adalah untuk mengajarkan, menuntun dan membimbing setiap orang keluar menuju Kerajaan Allah. Hal ini dijelaskan oleh Robert Boehlke bahwa Pendidikan Agama Kristen bertujuan untuk membimbing nara didik memahami dan menghayati Kasih Allah yang dinyatakan dalam diri Yesus Kristus. ${ }^{6}$ Tentunya hal yang dimaksud adalah mengaplikasikan kasih tersebut kepada lingkungan sekitar. Kemudian Djoys Anneke Rantung juga mengutip pendapat dari Thomas H. Groome yang menjelaskan bahwa tujuan dari Pendidikan Agama Kristen adalah untuk memampukan setiap orang agar hidup sebagai pengikut Kristus yang sejati, yakni hidup sesuai iman Kristen. ${ }^{7}$

Tujuan utama pendidik Kristen adalah menuntun setiap orang untuk keluar dari kegelapan menuju kepada terang yang ajaib. Dalam hal ini, Groome mengatakan bahwa Pendidikan Agama Kristen memiliki tugas penting untuk dapat membimbing setiap orang untuk menjadi kerajaan Allah masa kini. ${ }^{8}$ Lisa Karyawati mengutip pendapat dari J. M. Nainggolan dengan mengatakan, Pendidikan Agama Kristen memiliki tugas yang penting untuk meningkatkan pengetahuan dan pengenalan akan Firman Allah, dan memampukan murid agar dapat menyatakan keberadaan dirinya dalam kesehariannya serta memampukan murid untuk dapat hidup bersama dengan 142,144

4 Djoys Anneke Rantung, Pendidikan Agama Kristen Dalam Kehidupan Masyarakat Majemuk,

5 Djoys Anneke Ratung, Pendidikan Agama Kristen Untuk Keluarga Menurut Pola Asuh Keluarga Ishak Dalam Perjanjanjian Lama, Jurnal SHANNAN, Vol 1 Nomor 2 (2019): 149-200.

${ }^{6}$ Robert Beohlke, Sejarah Perkembangan Pikiran Dan Praktek Pendidikan Agama Kristen (Dari Yohanes Amos Comenius Sampai Perkembangan PAK Di Indonesia), (Jakarta: BPK Gunung Mulia, 2011)

7 Djoys Anneke Ratung, Pendidikan Agama Kristen Dalam Kehidupan Masyarakat Majemuk.

8 Tafonao, Pendidikan Agama Kristen Dalam Masyarakat Majemuk, 64. 
orang lain di lingkungan sekitar. ${ }^{9}$ Berdasarkan pengertian dan tujuan Pendidikan Agama Kristen yang diuraikan di atas, maka Pendidikan Agama Kristen mengajarkan kepada setiap anak-anak Tuhan untuk mengenal Tuhan Yesus dengan benar berdasarkan pengajaran dari Alkitab. Menurut Elia Tambunan, Pendidikan Agama Kristen dapat mengimplementasikan Firman Tuhan yang dapat membawa perubahan pada seluruh dimensi kehidupan masyarakat dan sebagai media penginjilan untuk menjadikan semua orang dapat dewasa secara rohani. ${ }^{10}$ Dalam Konteks masyarakat majemuk, Pendidikan Agama Kristen diharapkan untuk hadir sebagai pemersatu, pembawa damai di tengah-tengah keberagaman kehidupan masyarakat. Salah satu cara untuk meningkatkan kualitas dari Pendidikan Agama Kristen di tengah kemajemukan adalah menjadi surat Kristus yang terbuka supaya dapat dibaca oleh semua orang (2 Kor. 3:2-3). Artinya bahwa keberadaan setiap orang yang percaya kepada Yesus Kristus mempraktekkan apa yang telah diajarkan oleh Yesus. Dengan demikian, maka Pendidikan Agama Kristen merupakan bagian dari misi Allah sehingga wajib untuk dilaksanakan yang mana dapat mengajarkan nilai-nilai Injil Kerajaan Allah untuk mencapai visi Allah yaitu "Shalom/syalom yang berarti damai sejahtera". Sudah sepatutnya kehadiran Pendidikan Agama Kristen membawa dampak positif yaitu sikap inklusif bukan eksklusif di tengah kehidupan kemajemukan dengan cara menciptakan perdamaian dan keadilan.

\section{Inklusivisme}

Inklusivisme merupakan keterbukaan untuk menerima keberadaan dari orang lain. Menurut Supriatno, dkk., menjelaskan bahwa inklusivisme yaitu paham yang memiliki pandangan bahwa semua agama itu memiliki kebenaran. Di mana paham ini memiliki keterbukaan untuk menerima keberadaan kebenaran agama lain. ${ }^{11}$ Sedangkan Knitter menjelaskan demikian, inklusivisme adalah sikap yang bersifat umum terhadap penganut agama lain, yang mana memiliki tantangan dari berbagai hal, baik itu dalam budaya, kebenaran yang dipercayai, cara beribadah dan perbedaan lainnya. Sehingga dalam hal ini, kesadaran akan adanya perbedaan tersebut dapat menjadi sebuah keindahan. Kemudian Knitter melanjutkan penjelasannya lagi yang lebih spesifik kepada konteks gereja, yaitu gereja-gereja Protestan pun harusnya

${ }^{9}$ Lisa Karyawati, "Konsep Pembelajaran Pendidikan Agama Kristen Dalam Masyarakat Majemuk," Jurnal Teologi dan Pendidikan Kristen 1, no. 2 (2019): 140-153.

${ }^{10}$ Elia Tambunan, Pendidikan Agama Kristen: Handbook Untuk Pendidikan Tinggi (YogyakartaIndonesia, 2013), 45-46.

${ }^{11}$ Daryatno Supriatno, Onesimus Dani, Merentang Sejarah, Memaknai Kemandirian (Jakarta: BPK Gunung Mulia, 2009), 158. 
mengakui kehadiran Allah yang menyatakan diri dan menyelamatkan semua orang sepanjang sejarah. Artinya bahwa kasih Allah itu berlaku untuk semua orang. ${ }^{12}$

\section{Inklusivisme Dalam Alkitab \\ Perjanjian Lama}

Kemajemukan adalah kenyataan yang tidak dapat dibatasi dan ditolak. Dalam Perjanjian Lama, diperlihatkan adanya kemajemukan atau keberagaman baik itu budaya maupun agama. Pertemuan Abraham dan Sara merupakan kisah yang membawa mereka pada perjumpaan keberagaman suku bangsa yaitu Moab, Mesir, Sodom dan Gomora. Perjumpaan tersebut bukan hanya konteks suku bangsa melainkan kepercayaan yang berbeda pula. Kemudian, kisah Yunus juga memperlihatkan akan kasih Allah untuk bangsa-bangsa lain serta bukti dari didikan Allah terhadap umat-Nya untuk saling menerima perbedaan baik adat istidat maupun agama (bnd. Yun. 1:1-17). ${ }^{13}$

Ketika melihat sejarah daripada bangsa Israel, maka kisah tersebut sebagai implikasi dari sikap penolakan terhadap pluralitas dan toleransi sehingga ada bangsa-bangsa lain yang diperangi dan dikuasai. Namun demikian, muncullah pengakuan terhadap otoritas dan perlindungan Allah terhadap bangsa-bangsa lain. Stanley Rambitan mengatakan bahwa pada kenyataannya Firman Tuhan melalui nabi Yesaya (Yes. 19:19-21) terdapat pengakuan terhadap bangsa-bangsa lain selain Israel seperti Mesir dan Asyur sebagai bangsa yang diberkati Allah. Kemudian nabi Yesaya juga mengatakan, bahwa bangsa-bangsa lain adalah sama dengan bangsa Israel dan sebaliknya (Yes. 19:23-25). ${ }^{14}$ Tambahan lagi, yang menunjukkan bangsa lain sebagai alat dan sarana berkat Tuhan adalah pernyataan nabi Yesaya yang terdapat dalam Yesaya 45:1. Jadi, di sini terlihat jelas bahwa Raja Koresy yang adalah raja Persia dipakai Allah untuk menundukkan raja-raja bangsa lain ${ }^{15}$ sehingga dengan adanya pengakuan serta penerimaan dari bangsa lain maka mereka juga diakui, diberkati dan dipakai oleh Allah. Hal ini jelas merupakan wujud dari Kasih Allah kepada bangsa lain yang juga merupakan ciptaan Allah. ${ }^{16}$ Dengan demikian, sangat penting untuk dipahami bahwa bangsa Israel adalah bangsa pilihan Allah bukan berarti bangsa lain tidak mendapatkan berkat dan kasih dari Allah. Dalam Kitab Mazmur 145:9, Daud dengan jelas menyatakan bahwa: "Tuhan itu baik kepada semua orang, dan penuh rahmat terhadap segala yang dijadikan-Nya".

\footnotetext{
${ }^{12}$ Paul F. Knitter, Satu Bumi Banyak Agama-Dialog Multi-Agama Dan Tanggung Jawab Global (Jakarta: BPK Gunung Mulia, 2012), 39.

${ }^{13}$ Djoys Anneke Ratung, "Pendidikan Agama Kristen Dalam Kehidupan Masyarakat Majemuk," 109.

${ }^{14}$ Stanley R. Rambitan, “Pluralitas AGama Dalam PAndangan Kristen” 1, no. 1 (2017): 93-108.

15 Ibid.

${ }^{16}$ Ibid.
} 


\section{Perjanjian Baru}

Dalam konteks Perjanjian Baru, inklusisivime merupakan wujud Allah yang adalah kasih (1 Yoh. 4:8, Tit. 2;11; bnd. 1 Tim. 4;10). Kisah Para Rasul yang ditulis oleh Lukas juga memuat pengajaran Allah tentang penerimaan orang lain dengan tidak membedakan. ${ }^{17}$ Dalam kasih, tidak ada perbedaan. Allah memberikan contoh yaitu Ia tidak melihat latar belakang umat-Nya dengan mengasihi serta menerima semua orang dari berbagai latar belakang hidup, suku, ras, golongan, bangsa dan agama. Injil Yohanes mencatat bahwa Allah datang untuk menyelamatkan seluruh dunia (Yoh. 3:16).

Perjanjian baru juga mencatat pengajaran tentang memiliki sikap tidak memusuhi orang lain. Dalam Roma 12:18-19 terdapat pengajaran mengenai perilaku etis Kristiani. Kemudian dalam Matius 5:9, Yesus mengajarkan pengikut-Nya untuk tetap membawa damai. Tentunya hal ini memberikan pemahaman bahwa pengajaran Yesus membawa dampak yang sangat baik untuk menghargai dan menerima orang lain. Yesus menghargai perbedaan dan juga kemajemukan. ${ }^{18}$ Di sini Yesus memberikan teladan yang jelas terhadap bangsa dan agama lain dengan mengaku dan menerima mereka serta memperlakukan secara baik.

\section{Masyarakat Majemuk}

Menurut Stanley Rambitan, kemajemukan berarti keanekaragaman, yang berasal dari kata majemuk yaitu terdiri dari beberapa bagian yang merupakan kesatuan. ${ }^{19}$ Talizaro Tafona'o menjelaskan bahwa masyarakat majemuk adalah suatu kelompok yang menganut banyak corak perbedaan. ${ }^{20}$ Kemudian Talizaro juga mengutip pendapat Ibrahim Saad, yang menjelaskan bahwa masyarakat majemuk adalah masyarakat yang terdiri atas kelompok-kelompok, yang tinggal bersama dalam suatu wilayah, tetapi terpisah menurut garis budaya masing-masing. Kemajemukan suatu masyarakat patut dilihat dari dua variabel yaitu pertama, kemajemukan budaya yang mana ditentukan oleh indikator-indikator genetik sosial (ras, etnis, suku), budaya (kultur, nilai, kebiasaan), bahasa, agama, kasta, ataupun wilayah. Kedua, kemajemukan sosial ditentukan indikator-indikator seperti kelas, status, lembaga, ataupun power. ${ }^{21}$ Menurut Parsudi Suparlan, Indonesia adalah bangsa yang majemuk. Cirinya dapat ditemukan pada penekanan akan pentingnya

${ }^{17}$ Olaf Herbert Schumann, Agama Dalam Dialog: Pencerahan, Pendamaian Dan Masa Depan Punjung Tulis 60 Tahun (Jakarta: BPK Gunung Mulia, 2003), 131. 109-110.

${ }^{18}$ Djoys Anneke Ratung, Pendidikan Agama Kristen Dalam Kehidupan Masyarakat Majemuk,

${ }^{19}$ Versi Online/Daring, "Kamus Besar Bahasa Indonesia," n.d.

20 Tafonao, Pendidikan Agama Kristen Dalam Masyarakat Majemuk, 34.

21 Ibid. 
kesukubangsaan yang terwujud dalam bentuk komunitas suku bangsa, dan digunakannya kesukubangsaan sebagai acuan utama bagi jati diri. Oleh karena itu, dikatakan bahwa sekalipun masyarakat Indonesia sebagai masyarakat yang majemuk namun tetap memiliki satu status dan kedudukan yang sama yakni sebagai masyarakat Indonesia yang memiliki hak dan kewajiban yang sama sebagai warga negara Indonesia, yang mana dituntut untuk bersatu menjunjung tinggi keutuhan NKRI. ${ }^{22}$

Dalam bukunya, Talizaro Tafona'o menguraikan jenis-jenis masyarakat majemuk menjadi beberapa kategori, yakni: Kemajemukan dengan kekuatan kompetisi yang seimbang, kemajemukan lebih dominan kepada mayoritas sehingga tidak memiliki keseimbangan dan kekuatan kompetitif, kemajemukan yang lebih dominan kepada minoritas tetapi juga dapat memiliki kekuatan kompetitif dalam bidang politik dan ekonomi, kemajemukan dengan fragmentasi yaitu terdiri dari beberapa kelompok etnik dalam jumlah yang kecil sehingga tidak ada yang lebih dominan baik dalam bidang politik maupun ekonomi. ${ }^{23}$

\section{Pembelajaran PAK di Era Digital: Sikap Inklusivisme di Tengah Kemajemukan}

Di Era digital, diupayakan agar pembelajaran Pendidikan Agama Kristen mampu mengatasi sikap eksklusivisme peserta didik. Peran Pendidikan Agama Kristen di era digital adalah membebaskan murid dari ikatan-ikatan tertentu di mana sikap inklusif menjadi pilihan dalam upaya pengembangan toleransi dan memiliki kemampuan untuk berdialog di tengah masyarakat majemuk Indonesia. Melihat bahwa tujuan pendidikan adalah untuk membimbing dan mengarahkan, maka dalam konteks ini Pendidikan Agama Kristen yang inklusif perlu untuk dikembangkan agar menghasilkan nara didik yang menghargai setiap perbedaan serta menghargai nilainilai kemanusiaan dalam kehidupannya.

Pembelajaran Pendidikan Agama Kristen adalah proses pembelajaran yang didasarkan pada Alkitab. Dalam hal ini, Pendidik Pendidikan Agama Kristen bertugas untuk mengajarkan berita keselamatan kepada peserta didik. Inilah yang menjadi ciri khas Pendidikan Agama Kristen dari pendidikan umum lainnya. Isi dari Pendidikan Agama Kristen adalah pengajaran Yesus Kristus. Dalam artikelnya, Lenda Dabora Sagala mengutip pendapat John M. Nainggolan yang mengatakan bahwa, isi Pendidikan Agama Kristen adalah pengajaran iman Kristen dengan tujuan membantu peserta didik untuk mengalami perjumpaan secara pribadi bersama Tuhan. ${ }^{24}$

22 Ordianto Lahagu, "Menyikapi Tantangan Dan Harapan Pendidikan Agama Kristen Dalam Masyarakat Majemuk," STT Real Batam (n.d.): 95-115.

${ }^{23}$ Tafonao, Pendidikan Agama Kristen Dalam Masyarakat Majemuk, 37.

${ }^{24}$ Lenda Dabora Sagala, "Peran Pendidikan Agama Kristen Dalam Menghadapi Perubahan Sosial," Jurnal Simpson: Jurnal Teologi dan Pendidikan Agama Kristen 1, no. 1 (2017): 48. 
Terlepas dari amanat Tuhan Yesus yang semuanya tercantum dalam Alkitab, isi pendidikan Kristen diupayakan untuk memiliki cakupan dari berbagai hal baik itu tentang lingkungan dan kehidupan dunia nyata lainnya. ${ }^{25}$ Menurut Judith Debora Listia Wangania, Pendidikan Agama Kristen harus terus mengembangkan sikap saling mengakui bahwa kita semua satu iman, satu baptisan dan satu pengharapan di dalam Yesus Kristus, yang diikat oleh kasih. Pendidikan Agama Kristen juga memiliki tugas untuk melaksanakan amanat agung Kristus yang diwujudkan melalui bersaksi, bersekutu dan melayani. Selain itu, Pendidikan Agama Kristen diharuskan untuk menghadirkan persatuan di tengah kehidupan masyarakat yang majemuk. ${ }^{26}$ Artinya bahwa Pendidikan Agama Kristen harus mampu untuk menjangkau keragaman di dalam masyarakat.

\section{Pembelajaran PAK Dalam Kehidupan Masyarakat Majemuk Meningkatkan Kesadaran Untuk Mampu Hidup Bertoleransi}

Toleransi adalah bentuk akomodasi dari interaksi sosial. Toleransi dapat dipahami sebagai persiapan untuk kerja sama dengan orang lain yang memiliki perbedaan yang fundamental di mana terdapat banyak konflik dalam cara hidup dan keyakinan. Toleransi juga memerlukan penanaman nilai keterbukaan dan saling menerima setiap perbedaan yang menjadi realitas dalam kehidupan sehari-hari. Toleransi dalam kemajemukan haruslah terus dibangun sebagai prasyarat keberadaan dari kemajemukan yang ada dalam kehidupan masyarakat. Pendidikan Agama Kristen mengacu pada pengajaran dari Yesus. Stanley R. Rambitan mengatakan bahwa, Keteladananan toleransi yang diperlihatkan oleh Yesus adalah ketika muncul karya Yesus dan pada mulanya dinyatakan pada kalangan kehidupan masyarakat dan agama Yahudi dan saat itu juga pluralitas sudah menjadi bagian didalamnya. ${ }^{27}$

Teladan hidup sekaligus pengajaran Tuhan Yesus, nilai-nilai toleransi dapat diwariskan untuk wajib dinyatakan dalam kehidupan orang percaya dalam pikiran serta tindakannya. Ajaran toleransi dari Yesus terlihat tegas, lugas dan jelas tetapi mudah diterima. Melihat hal demikian, seharusnya gereja Tuhan tanpa ragu mengedukasi jemaat supaya memiliki standar berpikir dan bertindak sesuai Alkitab. ${ }^{28}$

\footnotetext{
${ }^{25}$ Fransiskus Irwan Widjaja, "Pluralitas Dan Tantangan Misi : Kerangka Konseptual Untuk Pendidikan Agama," Regula Fidei: Jurnal Pendidikan Agama Kristen 4, no. 1 (2019): 1-13.

${ }^{26}$ Judith Debora and Listia Wangania, "Mengembangkan Pendidikan Perdamaian Dalam PAK," Sola Scriptura: Jurnal Teologi 1, no. 1 (2020): 73-93.

27 Casram Casram, "Membangun Sikap Toleransi Beragama Dalam Masyarakat Plural," Wawasan: Jurnal Ilmiah Agama dan Sosial Budaya 1, no. 2 (2016): 187-198.

${ }^{28}$ Manahan Uji Simanjuntak, Rikardo Dayanto Butar-Butar, Ester Lina Situmorang, Jabes Pasaribu, "Pengajaran Tuhan Yesus Mengenai Toleransi Dan Implementasinya Ditengah Masyarakat Majemuk," Real didache: Jurnal Teologi dan Pendidikan Agama Kristen 4, no. 1 (2019): 88-101.
} 
Terdapat beberapa contoh pengajaran toleransi sebagai berikut: (1) Perintah untuk saling mengasihi (Yoh. 15:12, 17; Mat. 7:12). Perintah untuk mengasihi sesama manusia seperti diri sendiri adalah pengajaran dan sikap tertinggi tentang toleransi. Setiap orang adalah sesama yang wajib dikasihi, dihormati, ditolong, diperhatikan tanpa dibebani oleh pertimbangan keyakinan agama dan keyakinan orang lain. ${ }^{29}$ Standar mengasihi dan memperlakukan orang lain yang ditetapkan dan diajarkan Tuhan Yesus adalah seperti mengasihi diri sendiri. Standar ini sangat mudah, sederhana, mudah dicerna dan diterima. Setiap orang harus diperlakukan sebagaimana memperlakukan diri sendiri. Artinya bahwa, seperti yang sudah diajarkan oleh Yesus dalam Matius 22:37-40 untuk hidup saling mengasihi. Di tengah kemajemukan, mengasihi menjadi hal yang sangat penting. (2)Teladan penerimaan Yesus kepada Perempuan Samaria (Yoh. 14:9). Penerimaan terhadap perempuan Samaria adalah bentuk pengajaran yang disampaikan oleh Yesus dengan mempraktekkannya secara langsung untuk meruntuhkan tembok intoleransi orang Yahudi terhadap orang Samaria untuk saling menerima. ${ }^{30}$ Dari teladan penerimaan Yesus terhadap perempuan Samaria disampaikan pesan dan ajaran bahwa Yesus tidak pernah setuju dengan perbuatan intoleransi. (3) Yesus mengambil keputusan untuk tidak menghukum perempuan yang tertangkap basah berbuat zinah (Yoh. 8:3). Demikian terdapat pemahaman bahwa penerimaan, maaf, pengampunan, kasih adalah sikap dari toleransi. Dosa perzinahan perempuan tersebut sama sekali tidak dapat ditoleransi, namun Tuhan Yesus memberikan pelajaran tentang makna toleransi. Hukum harus ditegakkan namun kasih dan penerimaan memampukkan manusia memahami bahwa semua orang memiliki sisi gelapnya masing-masing (Yoh. 8:7). ${ }^{31}$ Ajaran Tuhan Yesus tentang toleransi, atau sikap menerima sesama dalam kasih Kristus menyadarkan kita bahwa kita semua adalah orang berdosa yang tidak luput dalam dosa dan kelalaian.

\section{Meningkatkan Kesadaran Untuk Menghargai Perbedaan Dalam Melakukan Interaksi Sosial}

Dalam berinteraksi sosial, sikap untuk saling menghargai sangat diperlukan, di mana sikap tersebut sebagai wujud dari menjunjung tinggi harkat dan martabat kesetaraan. Sikap saling menghargai menjadi sifat dasar dalam seluruh aspek kehidupan manusia yang menjaga kehormatan diri bukan berarti harus mengorbankan atau mengalahkan harga diri orang lain. Talizaro berpendat bahwa, setiap manusia haruslah dihargai sebagaimana ia ada. Tidak ada alasan bagi kita untuk tidak menghargai orang lain. Sikap saling pengertian juga melibatkan tindakan

\footnotetext{
${ }^{29}$ Ibid, 94

${ }^{30}$ Ibid, 95.

${ }^{31}$ Ibid, 97.
} 
saling menghargai. Sikap saling menghargai adalah menjunjung tinggi harkat dan martabat kesetaraan. Saling menghargai adalah sifat dasar yang melekat pada diri manusia. $^{32}$

Setiap orang percaya dari semua agama harus hadir sebagai pendamai yang menunjukkan rasa kebersamaan dan kesatuan di dalam suatu komunitas. Menahan Uji Simanjuntak menjelaskan bahwa dalam kehidupan beragama, perbedaan pikiran dan sikap bukan untuk membangun tembok perlawanan. Hal tersebut tentunya merupakan dasar dari tindakan setiap orang dalam kehidupan penganut agama tersebut, ${ }^{33}$ sehingga Yesus memberikan teladan bagaimana Ia sebagai Tuhan dan Juruselamat memberi penghargaan yang tulus dengan cara menerima semua orang dengan tidak pernah mempersoalkan latar belakang golongan, atau warna kulit dan lain sebagainya. Beberapa contoh Yesus menghargai dan menerima orang lain walaupun berbeda, yakni orang lumpuh di Kolam Betesda, Perempuan Samaria, anakanak kecil yang datang kepada-Nya bahkan orang tua yang sudah tidak berdaya. Artinya bahwa sikap saling menghargai sesama memungkinkan kita untuk dapat mendengarkan suara agama lain yang berbeda.

\section{Kesimpulan}

Dari pembahasan yang telah diuraikan di atas, maka sikap inklusivisme di tengah kehidupan masyarakat majemuk sudah seharusya ditetapkan dan diterapkan dalam pembelajaran Pendidikan Agama Kristen di era digital ini. Sehingga dengan adanya penanaman nilai-nilai kristiani yang baik dan benar seperti yang telah dilakukan oleh Yesus seperti kasih, saling menghargai, menerima perbedaan kepada peserta didik sejak dini melalui pembelajaran Pendidikan Agama Kristen, maka tentunya dapat membebaskan mereka dari sikap fanatisme, intoleransi dan sikap ekslusivisme. Yesus sebagai Guru Agung, telah memberikan banyak contoh tentang sikap inklusivisme yang mana menerima semua orang tanpa melihat perbedaan.

Pembelajaran Pendidikan Agama Kristen di era digital ini perlu terus dikembangkan termasuk bagaimana nara didik berperilaku sesuai dengan ajaran Yesus di mana memahami dan menghargai perbedaan. Singkatnya bahwa Pendidikan Agama Kristen memberikan pengajaran kepada peserta didik untuk tetap menjadi pemersatu pada setiap keberadaannya. Sebagaimana telah dirumuskan pada pembahasan di atas bahwa terdapat beberapa hal penting untuk dilakukan dalam pembelajaran Pendidikan Agama Kristen di tengah kemajemukan, yaitu dapat meningkatkan kesadaran untuk mampu hidup bertoleransi, kemudian dapat

\footnotetext{
${ }^{32}$ Tafonao, "Pendidikan Agama Kristen Dalam Masyarakat Majemuk", 148-149.

${ }^{33}$ Widjaja, "Pluralitas Dan Tantangan Misi : Kerangka Konseptual Untuk Pendidikan Agama.", 7 .
} 
meningkatkan kesadaran untuk menghargai perbedaan dalam melakukan interaksi sosial.

\section{Referensi}

Badan Pusat Statistik. "Penduduk Indonesia Menurut Propinsi Tahun 2010." Last modified 2010.http://www.bps.go.id/tab_sub/view.php?tabel=1\&id_subyek=12.

Butar-Butar, Rikardo Dayanto. Situmorang, Ester Lina., Pasaribu, Jabes. Manahan Uji Simanjuntak. "Pengajaran Tuhan Yesus Mengenai Toleransi Dan Implementasinya Ditengah Masyarakat Majemuk." Real didache: Jurnal Teologi dan Pendidikan Agama Kristen 4, no. 1, 2019.

Casram. "Membangun Sikap Toleransi Beragama Dalam Masyarakat Plural." Wawasan: Jurnal Ilmiah Agama dan Sosial Budaya 1, no. 2, 2016.

Debora, Judith, and Listia Wangania. "Mengembangkan Pendidikan Perdamaian Dalam PAK." Sola Scriptura: Jurnal Teologi 1, no. 1, 2020.

Flick, Uwe. An Introduction to Qualitative Research. London: SAGE Publications, Ltd., 2014.

Karyawati, Lisa. "Konsep Pembelajaran Pendidikan Agama Kristen Dalam Masyarakat Majemuk.” Jurnal Teologi dan Pendidikan Kristen 1, no. 2,2019.

Knitter, Paul F. SATU BUMI BANYAK AGAMA-Dialog Multi-Agama Dan Tanggung Jawab Global. Jakarta: BPK Gunung Mulia, 2012.

Lahagu, Ordianto. "Menyikapi Tantangan Dan Harapan Pendidikan Agama Kristen Dalam Masyarakat Majemuk." STT Real Batam (n.d.).

Robert, Boehlke. "Sejarah Perkembangan Pikiran Dan Praktek Pendidikan Agama Kristen (Dari Yohanes Amos Comenius Sampai Perkembangan PAK Di Indonesia". Jakarta: BPK Gunung Mulia, 2011.

Rabitan, Stanley R. "Pluralitas Agama Dalam Pandangan Kristen", Volume1, Nomor 1, 2017.

Rantung, Djoys Anneke. "Pendidikan Agama Kristen Dalam Kehidupan Masyarakat Majemuk". Yogyakarta: Lintang Rasi Aksara Books, 2017.

- - - "Pendidikan Agama Kristen Untuk Keluarga Menurut Pola Asuh Keluarga Ishak Dalam Perjanjian Lama." Pendidikan Agama Kristen SHANAN 87, no. 1,2, 2019.

Sagala, Lenda Dabora. "Peran Pendidikan Agama Kristen Dalam Menghadapi Perubahan Sosial." Jurnal Simpson: Jurnal Teologi dan Pendidikan Agama Kristen 1, no. 1, 2017.

Schumann, Olaf Herbert. Agama Dalam Dialog: Pencerahan, Pendamaian Dan Masa Depan Punjung Tulis 60 Tahun. Jakarta: BPK Gunung Mulia, 2003.

Sianipar, Desi. Peran Pendidikan Agama Kristen Di Gereja Dalam Meningkatkan Ketahanan Keluarga. Jurnal Shanan Volume 4 Nomor 1, 2020. 
Supriatno, Onesimus Dani, Daryatno. "Merentang Sejarah: Memaknai Kemandirian". Jakarta: BPK Gunung Mulia, 2009.

Talizaro, Tafonao. Pendidikan Agama Kristen Dalam Masyarakat Majemuk, 2015.

Tambunan, Elia. Pendidikan Agama Kristen: Handbook Untuk Pendidikan Tinggi. Yogyakarta-Indonesia, 2013.

Versi Online/Daring. "Kamus Besar Bahasa Indonesia," n.d.

Widjaja, Fransiskus Irwan. "Pluralitas Dan Tantangan Misi: Kerangka Konseptual Untuk Pendidikan Agama." Regula Fidei: Jurnal Pendidikan Agama Kristen 4, no. 1, 2019. 